Emir. J. Food Agric. 2008. 20 (2): 41-50

http://www.cfa.uaeu.ac.ae/research/ejfa.htm

\title{
Use of triticale grains in broiler chick diets containing dry fat
}

\author{
Mutassim M. Abdelrahman ${ }^{1}$, Ayed M. AlOmary ${ }^{2}$ and Moyad Al- Hamadani ${ }^{3}$ \\ ${ }^{1}$ Department of Animal Production, ${ }^{2}$ Dept of plant production, Mu'tah University, P.O.Box 7 \\ Karak, Jordan. ${ }^{3}$ Faculty of Agric. and Science, Jerash University, P.O.Box 311, Jerash, \\ Jordan
}

\begin{abstract}
The present study was conducted using 400 Ross chicks to determine the efficiency of partial substitution of corn with triticale grain and dry fat (Feedar) on the broiler performance, meat quality and mineral utilization. The chicks were arranged as a complete block design with four treatments and 4 replicate/ treatment ( 25 chicks/ replicate). The treatments were diet 1: basal diet (corn representing 100\% of grain component and corn oil - C); diet 2: (corn representing $100 \%$ of grain component and dry fat - T0); diet 3: $(50 \%$ corn and $50 \%$ triticale of grain components and dry fat - T50); diet $4:(75 \%$ corn and $25 \%$ triticale of grain components and dry fat - T25). Weekly body gain, feed intake were recorded. At slaughter, blood and liver samples were collected for further analysis. Results showed no significant difference $(\mathrm{P}>0.05)$ between chicks from C, T50 and T25 in term of total weight gain compared to chicks from T0. Feed intakes were significantly higher in chicks in the T50 group compared with other groups. The feed conversion ratios were significantly higher in chicks fed different levels compared with the control and T0 groups. Moreover, there were no significant effect of treatments on the concentration of $\mathrm{Cu}, \mathrm{Zn}$ and $\mathrm{Mn}$ in liver, but $\mathrm{Mg}$ and $\mathrm{Co}$ were affected. Carcass dressing and abdominal fat percentages were not affected by the treatments, but lipid percentage in breasts and drumsticks were significantly higher $(\mathrm{P}<0.05)$ with added dry fat and triticale when compared to the control group. In conclusion, triticale decreased weight gain during the first three weeks and increased the final feed conversion by almost $20 \%$. However, triticale grain can replace corn up to $50 \%$.
\end{abstract}

Key words: Broiler, dry fat, triticale, abdominal fat, dressing percentage.

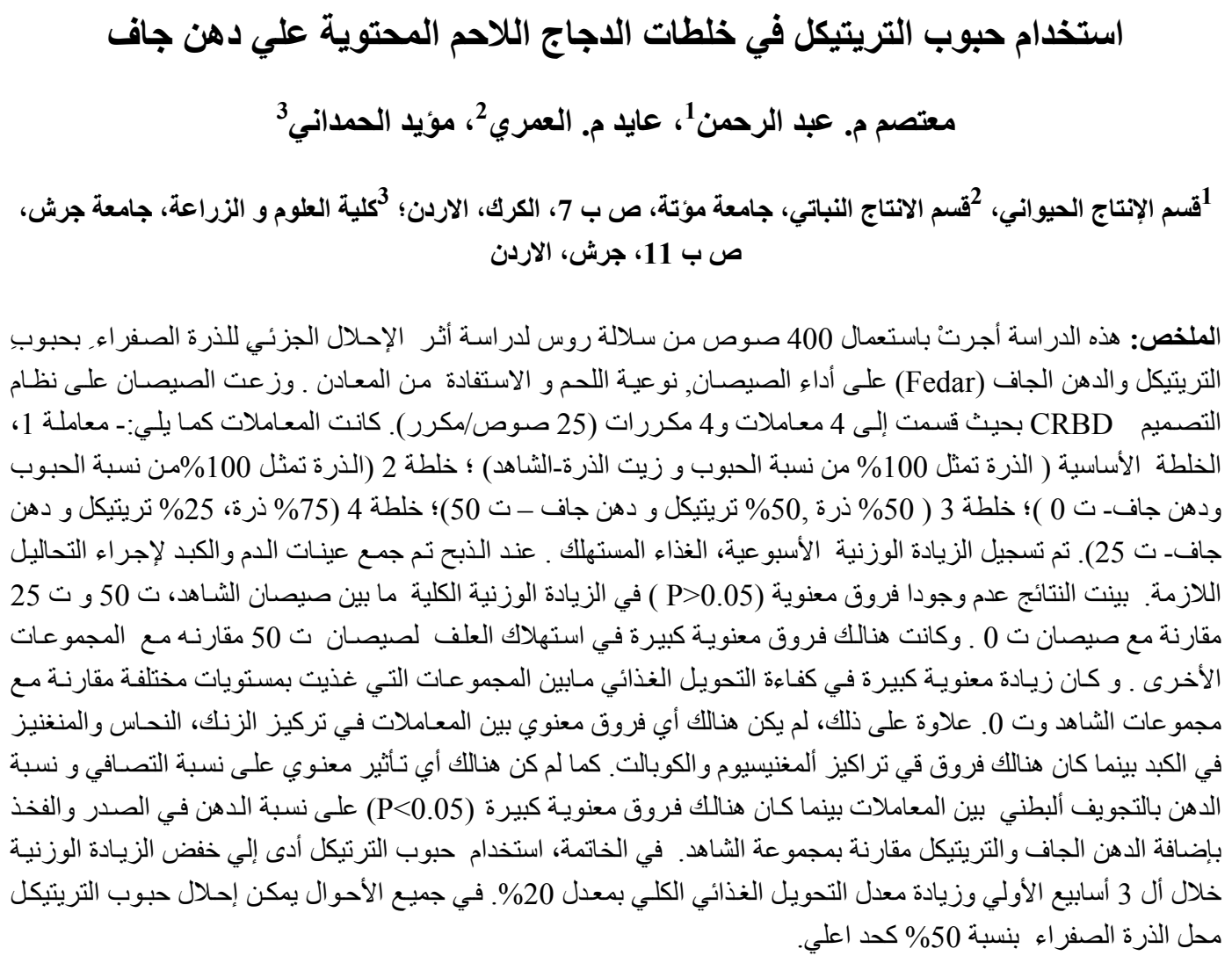




\section{Introduction}

The feed cost for poultry production is about $60-70 \%$ of the total cost production, and energy alone contributes about $70 \%$ of the feed cost (Wilson and Bayer 2000; Saleh et al., 2004). This suggests that in order to minimize the feed cost and maximize profit, the producer must use the cheapest form of energy as a substitute for corn maize (the main component of broiler diet) and obtain a greater growth rate with lower cost. Dry fat has recently been introduced to the Jordanian market as a source of energy at a cheaper price than corn oil. Moreover, dry fat helps to reduce dust, which may have adverse effects on the birds' health. In addition, carcass quality should be considered based on human health and shelf life.

Triticale is an alternative cereal grain that is a hybrid of wheat and rye and appears to be a promising crop for farmers because of its high yield, drought tolerance and disease resistance (Gatel et al., 1985). The potential of triticale in broiler diets is based on the partial replacement of other energy source ingredients. There is some evidence that the lower levels of lysine and methionine + cystine in triticale could negatively affect the broiler performance when compared with corn (Proudfoot and Hulan, 1988) and wheat (Sell et. al., 1962). Braggy and Sharby (1970) reported that triticale can be use efficiently for broilers to replace other grains. However, despite the contradictory findings reported in the literature, Belaid (1994) concluded that there is sufficient evidence to suggest that triticale can be used safely in cereal based diets for broiler and layer chicks.

Many factors play an important role in mineral digestion, absorption and metabolism through synergistic or antagonistic interaction effects within dietary minerals which are not fully understood. Indeed, it is well known that changes in trace mineral absorption and excretion through the gastrointestinal tract are primary mechanisms for maintaining trace mineral homeostasis (King et al., 2000). With respect to the composition of the carbohydrate fraction, triticale contains arabinoxylans which may create a viscous environment within the intestinal lumen (Smits and Annison, 1996). Increased viscosity is associated with lower apparent metabolizable energy (Austin et al., 1999) as well as absorption of other nutrients, such as trace minerals, and incidence of wet and sticky droppings (Smits and Annison, 1996).

The purpose of this study was to compare the performance of broiler chicks fed diets containing triticale at different replacement levels of corn with added dry fat instead of corn oil.

\section{Materials and Methods}

A total of 400 one-day-old unsexed Ross $^{\mathrm{TM}}$ chicks were randomly distributed as a complete randomized block design into four equal treatments, each with four replicates ( 25 chicks/ replicate). The chicks were reared on wood shavings in pens in an open house. The area of each pen was 3 $\mathrm{m}^{2}(2 \mathrm{mX} 1.5 \mathrm{~m})$. Treatments were diet 1 : basal diet (corn-soybean- oil meal diet C); diet 2: (corn-soybean- dry fat meal diet - T0), diet 3: (corn 50\% of grain component and 50\% Triticale - T50); and diet 4: (corn $75 \%$ of grain component and $25 \%$ Triticale - T25). The chemical composition of triticale used in this study was $87.3 \%$ dry matter, $11.2 \%$ crude protein, $1.8 \%$ crude fiber, $1.25 \%$ ether extract, $1.90 \%$ ash, $3315 \mathrm{Kcal} / \mathrm{kg}$ metabolizable energy, $0.57 \%$ lysine and $0.41 \%$ methionine; which was provided by the International Center for Agricultural Research in the Dry Area (ICARDA). Moreover, the chemical composition of the dry fat (Fedar) used in $t$ his study were: GE, $7400-7600 \mathrm{Kcal} / \mathrm{kg}$, 95-97.5\% dry matter, ash, $18-20 \%, 7.5-8.5 \%$ calcium which used to replace corn oil in the diets.

All rations were formulated by using the BLP88 ${ }^{\mathrm{TM}}$ computer program for formulating least cost rations. All rations 
Emir. J. Food Agric. 2008. 20 (2): 41-50

http://www.cfa.uaeu.ac.ae/research/ejfa.htm

in the starter and finisher periods were formulated to be isocaloric and isonitrogenous according to NRC (1994) recommendations. Table 1 shows the ingredients and chemical composition of the starter and finisher diets with inclusion of triticale grains and dry fat (Feedar). The chicks were fed starter rations from one day of age to 21 days of age and finisher ration from 22 to 42 days which was when they were ready for marketing. Live body weight, feed intake and feed conversion

ratio were recorded weekly up to the $6^{\text {th }}$ week of age. Five chicks from each replicate were slaughtered, after overnight fasting of feed, by severing the jugular vein, and blood, liver, breast and drumsticks were collected for further lab work. Abdominal fat (surrounding the gizzard, cloaca and adjacent abdominal muscles) was removed and weighted for calculations. Hot carcass weights were recorded and dressing percentages calculated as a percent of live weight.

Table 1. Chemical composition of experimental diets.

\begin{tabular}{lcccccccc}
\hline Ingredient & Starter & Starter & Starter & Starter & Finisher & Finisher & Finisher & Finisher \\
\hline Corn & 54.223 & 54.40 & 27.81 & 40.90 & 60.38 & 60.46 & 30.95 & 45.775 \\
Triticale & - & - & 27.00 & 13.50 & - & & 30.0 & 15.0 \\
Soybean meal & 36.70 & 36.51 & 35.00 & 36.02 & 30.0 & 30.0 & 28.0 & 29.0 \\
Corn oil & 3.10 & - & - & - & 3.6 & - & - & - \\
Dry fat (Fedar) & - & 4.00 & 5.5 & 4.7 & - & 4.5 & 2.5 & 5.5 \\
Fish meal & 2.50 & 2.50 & 2.5 & 2.5 & 2.50 & 2.5 & 6.4 & 2.50 \\
Dicalcium phosphate & 1.65 & 1.65 & 1.55 & 1.60 & 1.55 & 1.55 & 1.45 & 1.50 \\
Limestone & 1.14 & 0.25 & - & 0.12 & 1.20 & 0.22 & - & - \\
Methionine & 0.17 & 0.17 & 0.16 & 0.16 & 0.14 & 0.14 & 0.130 & 0.135 \\
Lysine & 0.047 & 0.05 & 0.01 & 0.03 & 0.14 & 0.14 & 0.10 & 0.120 \\
Salt & 0.30 & 0.30 & 0.30 & 0.30 & 0.32 & 0.32 & 0.30 & 0.300 \\
Vit+Min.* & 0.10 & 0.10 & 0.10 & 0.10 & 0.10 & 0.10 & 0.10 & 0.100 \\
Choline & 0.07 & 0.07 & 0.07 & 0.07 & 0.07 & 0.07 & 0.07 & 0.07 \\
& $100 \%$ & $100 \%$ & $100 \%$ & $100 \%$ & $100 \%$ & $100 \%$ & 1005 & $100 \%$ \\
Calculated chemical composition & & & & & & & \\
ME kcal/kg & 3000 & 3000 & 3000 & 3000 & 3100 & 3100 & 3100 & 3100 \\
Cp\% & 22.5 & 22.5 & 22.5 & 22.5 & 20.0 & 20.0 & 20.0 & 20.0 \\
Methionine (\%) & 0.54 & 0.54 & 0.54 & 0.54 & 0.48 & 0.48 & 0.48 & 0.48 \\
Lysine (\%) & 1.3 & 1.3 & 1.3 & 1.3 & 1.2 & 1.2 & 1.2 & 1.2 \\
Fiber (\%) & 3.75 & 3.75 & 3.75 & 3.75 & 3.5 & 3.5 & 3.5 & 3.5 \\
Calcium (\%) & 1 & 1 & 1 & 1 & 0.98 & 0.98 & 0.98 & 0.98 \\
Available P (\%) & 0.46 & 0.46 & 0.46 & 0.46 & 0.43 & 0.43 & 0.43 & 0.43 \\
Sodium (\%) & 0.17 & 0.17 & 0.17 & 0.17 & 0.17 & 0.17 & 0.17 & 0.17 \\
\hline * Vitamin and & & & & & &
\end{tabular}

${ }^{*}$ Vitamin and mineral premix: ${ }^{b}$ Every 1 gram of premix contained: vitamin $A=1500$ IU; Vit. $D 3=150$; Vit. $\mathrm{E}=200$ ug; Vit. $\mathrm{B} 1=200$ ug; vit. $\mathrm{B} 2=200 \mathrm{ug}$; vit. $\mathrm{B} 6=300 \mathrm{ug}$; vit. $\mathrm{B} 12=0.5$ ug; vit. $\mathrm{K} 3=200 \mathrm{ug}$; Folic acid $=30 \mathrm{ug}$; Panth. Acid $=550 \mathrm{ug}$ and Nicotinamide $=1 \mathrm{mg}$. Minerals: $\mathrm{Fe}_{2} \mathrm{SO} 4=550 \mathrm{ug}$ : $\mathrm{Mn} 2 \mathrm{SO} 4=450$ ug; $\mathrm{Zn}_{2} \mathrm{SO} 4=230$ ug; $\mathrm{Cu}_{2} \mathrm{SO} 4=56$ ug $\mathrm{Ca} 2 \mathrm{CO} 3=14$ ug.

Serum samples were separated by centrifugation of the blood at $3000 \mathrm{rpm}$ for 15 minutes. Liver samples were dried at $105^{\circ} \mathrm{C}$ overnight, reduced to ash by a muffle furnace $\left(600^{\circ} \mathrm{C} / 6 \mathrm{hrs}\right)$ and prepared for trace mineral analysis according to AOAC (1990) using an atomic absorption spectrophotometer. Moreover, breast and drumstick samples were analyzed for crude protein and ether extract percentages following the method of AOAC (1990).

Data were analyzed by analysis of variance (ANOVA) using SPSS ${ }^{\mathrm{TM}}$ version 10.0 as a complete randomized design and 
each pen considered a replicate. The Duncan multiple range test was used to determine differences among treatment means for significant dietary effect (Steel and Torrie, 1980), with $\mathrm{P}<0.05$ considered statistically significant unless otherwise noted.

\section{Results and Discussion}

\section{Broiler performance}

Table 2 shows the data of body weight gain, feed intake and feed conversion ratio during the starter ( 0 - 21 days), finisher (2242 days) and overall (0-42 days) periods. Inclusion of triticale in the broiler diets with different levels caused a significant $(\mathrm{P}=0.027)$ reduction in weight gain during the starter period, but not during the finishing and overall periods. The total body weigh gain of chicks fed dry fat were significantly $\quad(\mathrm{P}=0.037)$ lower when compared with the control (corn oil), but did not differ when compared with triticale groups (T50 and T25). The feed intakes were significantly increased with inclusion of triticale in the broiler diet from T50 during the finishing $(4.62 \mathrm{~kg})$ and overall periods when compared with the $\mathrm{C}, \mathrm{T} 0$ and T25. The inclusion of triticale (T25; $25 \%$ of corn) led to significant difference only during the finishing period, but not the overall feed intake when compared to the control and T0 diets. This may give an indication that inclusion of triticale in the broiler diet did not have a negative effect on diet palatability.

Variable results in triticale feeding experiments are reported in the scientific literature. Negative effects regarding the decrease in chicks' body weight by feeding triticale were observed by Korver et al., 2004) and others (Gerry, 1975; Ruiz et al., 1987; Smith et al., 1989) which disagreed with our findings. However, other researchers agreed with our results by reporting non-detrimental effect of triticale in poultry feeding trials. Johnson and Eason (1988) observed that growth of broiler chickens was similar whether triticale or wheat was the cereal source in diets that contained $50 \%$ cereal and were equalized for nutrient content. Similarly, Vieira et al. (1995) found that the graded inclusion of triticale up to $40 \%$ (substituted for corn) had no negative effect on weight gain or final weight of broilers. In those studies, the limited replacement of the main cereal grain might have hidden any negative effect of triticale. Elsewhere, poultry feeding studies shows that diets containing up to $30 \%$ triticale have had no negative effect on performance and result in significant saving of feed cost. Hermes and Johnson (2004) reported that feeding broiler chicks triticale up to $15 \%$ with corn did not affect their performance. Al- Athari and Bustany (1997) reported that inclusion of triticale up to $20 \%$ with $40 \%$ corn did not cause any significant effect on body weight when compared with the control (60\% corn), which agreed with our findings, but inclusion of triticale over $40 \%$ caused a significant reduction in body weight. Moreover, complete replacement of corn with triticale in the diet of White Leghorn pullets did affect body weight (Lesson and Summers, 1987). Further, Myer et al. (1996) reported a similar average daily gain in pigs a fed triticale based diet compared with the wheat or corn - soybean meal control diets.

The feed conversion ratios $(\mathrm{FCR})$ were significantly $(\mathrm{P}=0.0001)$ increased by inclusion of triticale in the diet during the finishing and overall period when compared with the control and T0. During the finishing period, FCR values for chicks fed dry fat (2.34) were significantly lower $(\mathrm{P}=0.0001)$ compared with the groups fed triticale (T50 and T25), but there was no significant difference between the groups fed triticale (T50 and T25). Moreover, the FCR values for chicks in the T50 $(50 \%$ triticale) group were significantly for the overall period when compared with chicks fed the T25 (25\% triticale) diet. This finding disagreed with Al- Athari and Bustany (1997) who reported a significantly lower FCR when chicks were 
fed a $20 \%$ triticale and $40 \%$ corn compared with the control. Moreover, Al- Thari and Bustany (1996) reported a significant increase in FCR when chicks were fed a diet containing $40.6 \%$ triticale with $19.2 \%$ corn when compared with the control group (57.5\% corn). The poorer FCR of the triticale-fed birds may be due to lower nutrient amounts, limited nutrient availability, or antinutritional factors not found to the same extent in wheat or corn. Antinutritional factors in triticale include soluble pentosans (Pettersson and Aman, 1988, Rundgren, 1988) trypsin inhibitor, alkyl resorcinols, and pectins (Smith et al., 1989). The viscosity of triticale extracts was highly correlated with the sum of water - extractable arabinoxylans and Bglucans (Mathlouthi et al., 2002). Likewise, the AME value of triticale was highly negatively correlated with the sum of pentosans and - B-glucans (Choct and Annison, 1990).

In some reports, triticale feeding has resulted in similar or improved feed efficiency relative to other grains. Ruiz et al. (1987) determined that feed efficiency was significantly better for chicks fed triticale than for those fed corn. In quail, Vohra et al. (1991) found no statistically significant differences in FCR among quail fed triticale- or corn- based diets to $21 \mathrm{~d}$ of age. However, other researchers have observed poorer FCR with triticale-based diets in broilers (Gerry, 1975; Proudfoot and Hulan, 1988; Vieira et al.(1995) Smith et al. (1989) reported 4 to $5 \%$ reduction in average FCR for broilers fed triticale compared with a corn control diet from 0 to $2 \mathrm{wk}$ and from $2 \mathrm{wk}$ to $3 \mathrm{wk}$ of age. Myer et al. (1996) found similar effects on FCR with pigs fed triticale or wheat.

Table 2. Effect of feeding triticale with dry fat on the performance of broiler chickens.

\begin{tabular}{|c|c|c|c|c|c|c|}
\hline \multirow[b]{2}{*}{ Measurement } & \multicolumn{6}{|c|}{ Treatments } \\
\hline & control $^{i}$ & T0 ${ }^{\mathrm{ii}}$ & T50 ${ }^{\mathrm{iii}}$ & $\mathrm{T}^{2} 5^{\mathrm{iv}}$ & SE & P value \\
\hline \multicolumn{7}{|l|}{ Weight gain (g) } \\
\hline $0-21$ days & $652 \mathrm{a}$ & $637 \mathrm{a}$ & $599 b$ & $583 \mathrm{~b}$ & 13.5 & 0.027 \\
\hline 22- 42 days & 1440 & 1340 & 1420 & 1400 & 18.6 & NS \\
\hline $0-42$ days & $2140 \mathrm{a}$ & $2020 \mathrm{~b}$ & $2070 \mathrm{ab}$ & $2040 \mathrm{ab}$ & 19.21 & 0.037 \\
\hline \multicolumn{7}{|l|}{ Feed intake (Kg) } \\
\hline 0 - 21 days & 1.55 & 1.52 & 1.53 & 1.56 & 0.011 & $>0.05$ \\
\hline 22- 42 days & $3.58 \mathrm{a}$ & $3.52 \mathrm{a}$ & $4.62 b$ & $4.18 \mathrm{c}$ & 0.137 & 0.0001 \\
\hline $0-42$ days & $5.10 \mathrm{a}$ & $5.02 \mathrm{a}$ & $6.04 \mathrm{~b}$ & $5.44 \mathrm{a}$ & 0.129 & 0.003 \\
\hline \multicolumn{7}{|l|}{ Feed conversion } \\
\hline 0- 21 days & 2.37 & 2.48 & 2.52 & 2.65 & 0.05 & $>0.05$ \\
\hline 22- 42 days & $2.44 a$ & $2.34 b$ & $2.42 \mathrm{c}$ & $2.40 \mathrm{c}$ & 0.018 & 0.0001 \\
\hline 0 - 42 days & $2.39 \mathrm{a}$ & $2.47 \mathrm{a}$ & $2.92 \mathrm{~b}$ & $2.78 \mathrm{c}$ & 0.065 & 0.0001 \\
\hline \multicolumn{7}{|c|}{ a,b,c means in rows with no common superscript differ significantly. } \\
\hline $\begin{array}{l}\text { Fed corn oil as a } \\
\text { Fed fat instead o } \\
\text { iii Fed fat with trit } \\
\text { Fed fat with trit } \\
\text { SE = Standard err }\end{array}$ & $\begin{array}{l}\text { nergy } \\
\text { s a source } \\
\text { cing } 50 \% \\
\text { ing } 25 \%\end{array}$ & $\begin{array}{l}\text { f energy } \\
\text { corn. } \\
\text { corn. }\end{array}$ & & & & \\
\hline
\end{tabular}




\section{Carcass characteristics}

The carcass characteristics of the broiler chicks fed dry fat and different levels of triticale are presented in Table 3. There were no significant differences between all groups in term of dressing and abdominal fat percentages, but numerically the abdominal fat percentages were higher for chicks fed dry fat (3.81\%) compared with other groups. There was a significantly $(\mathrm{P}=0.04)$ higher percentage of breast meat (hot carcass weight; CW) in chicks from the T0 and T25 compared with the chicks from the control and T50, but no difference between control and T50. The drumstick weight percentages were found to be significantly $(\mathrm{P}=0.05)$ lower in chicks from the T50 group compared with other groups. Moreover, there were no significant effect of the treatments on the protein percentages in the breast and drumstick meat, but there were significantly $(\mathrm{P}=0.03)$ higher levels of lipid percentage in breast and drumstick meat in chicks from the T0, T50 and T25 groups compared with the control group. Generally, once dietary fat is absorbed, saturated fatty acids (SFA) tend to be deposited in the body, while unsaturated fatty acids (USFA) tend to be oxidized to produce energy and heat (Beynen and Ketan, 1985). More unsaturated fatty acids from vegetable oil tend to produce lower energy retention and higher heat production in mice and humans (Mercer and Trayhum, 1987; Jones and Scheeler, 1988). Moreover, Shimomura et al. (1990) and Takeuchi et al. (1995) have found similar response by feeding rats safflower oil. These findings support our results which conclude that feeding higher saturated fatty acid as dry fat increases the deposition of fat in broiler tissues when compared with using vegetable oil.

Table 3. Effect of feeding triticale with dry fat on the carcass parameters of broiler chickens.

\begin{tabular}{|c|c|c|c|c|c|c|}
\hline \multirow[b]{2}{*}{ Measurements } & \multicolumn{5}{|c|}{ Treatments } & \multirow[b]{2}{*}{ P value } \\
\hline & Control $^{i}$ & $\mathbf{T 0}^{\mathrm{ii}}$ & T50 ${ }^{\mathrm{iii}}$ & $\mathrm{T}^{\mathrm{i} 5^{\mathrm{iv}}}$ & SE & \\
\hline Dressing out \%* & 72.9 & 72.7 & 71.5 & 72.0 & 0.296 & $>0.05$ \\
\hline $\begin{array}{l}\text { Abdominal } \\
\text { fat } \% * *\end{array}$ & 2.98 & 3.81 & 3.43 & 3.31 & 0.06 & $>0.05$ \\
\hline Breast \%(CW) & $22.0 \mathrm{a}$ & $25.4 \mathrm{~b}$ & $23.5 \mathrm{a}$ & $26.08 b$ & 1.21 & 0.04 \\
\hline Protein $\%$ & 22.1 & 22.43 & 22.35 & 22.39 & 0.76 & $>0.05$ \\
\hline Lipid\% & $1.56 \mathrm{a}$ & $2.37 \mathrm{~b}$ & $2.31 \mathrm{~b}$ & $2.21 \mathrm{~b}$ & 0.18 & 0.03 \\
\hline Drumstick\% (CW) & $14.8 \mathrm{a}$ & $14.05 \mathrm{a}$ & $13.18 \mathrm{~b}$ & $14.13 \mathrm{a}$ & 0.71 & 0.05 \\
\hline Protein \% & 19.8 & 19.35 & 19.16 & 19.47 & 0.82 & $>0.05$ \\
\hline Lipid\% & $4.76 \mathrm{a}$ & $5.12 \mathrm{~b}$ & $5.01 \mathrm{~b}$ & $4.96 \mathrm{~b}$ & 0.93 & 0.031 \\
\hline $\begin{array}{l}{ }^{\mathrm{a}, \mathrm{b}, \mathrm{c}} \text { means in rows } \\
{ }^{\mathrm{I}} \mathrm{Fed} \text { corn oil as a sol } \\
\text { ii }\end{array}$ & $\begin{array}{l}\text { th no comr } \\
\text { Irce of ene } \\
\text { rn oil as a } \\
\text { e replacing } \\
\text { e replacing } \\
\text { e is a prech } \\
\text { calculated } \\
\text { f means }\end{array}$ & $\begin{array}{l}\text { n supersc } \\
\text { arce of er } \\
\% \% \text { of co } \\
\% \text { of col } \\
\text { carcass } \\
\text { percent }\end{array}$ & $\begin{array}{l}\text { differ s } \\
\text { gy }\end{array}$ & $\begin{array}{l}\text { rcentas } \\
\text { d weig }\end{array}$ & $\begin{array}{l}\text { ive } \\
\text { orech }\end{array}$ & $\begin{array}{l}\text { ht. } \\
\text { arcass. }\end{array}$ \\
\hline
\end{tabular}


Korver et al. (2004) reported that feeding triticale to broiler had a negative effect on eviscerated carcass weight and many portion weights, but there was no defect when portions weight was expressed as a percentage of eviscerated carcass weight, which agreed with our findings. On the other hand, Charalambous et al. (1986) observed that carcass yield carcass plus edible giblets yield, and dressing percentage were higher in birds fed corn or corn - triticale diets than in broilers fed a diet with triticale as the only cereal grain.

\section{Trace minerals concentrations}

The trace minerals $\mathrm{Zn}, \mathrm{Cu}, \mathrm{Co}, \mathrm{Mn}$ and $\mathrm{Mg}$ are essential for human and animal nutrition, and are supplemented in animal diets to cover or exceed their nutritive requirements. The data of trace mineral concentration in the liver of chicks from different groups is reported in table 4. A significantly $\quad(\mathrm{P}=0.02) \quad$ higher $\mathrm{Co}$ concentration as a wet weight were found in chicks' liver fed dry fat (T0) compared with the control, but the concentration did not differ when compared with the chicks fed triticale (T50 and T25). Moreover, magnesium concentrations were found to be affected and significantly lower as a dry and wet weight in liver of chicks from the T25 (25\% triticale) group when compared with the other groups. On the other hand, triticale inclusion and use of dry fat did not cause any significant effect on the concentrations of $\mathrm{Cu}, \mathrm{Zn}$ and $\mathrm{Mn}$ (dry and wet weigh; DW and WW) in liver of chicks from all groups. Moreover, use of dry fat (Feedar) in the broiler diets which contain high levels of calcium (7.5-8.5\%) may affect the absorption of other minerals in the digestive system by different mechanisms.

Table 4. Effect of feeding triticale and dry fat on mineral concentrations in liver of broiler chickens.

\begin{tabular}{|c|c|c|c|c|c|c|}
\hline \multirow[b]{2}{*}{ Measurement } & \multicolumn{5}{|c|}{ Treatments } & \multirow[b]{2}{*}{$P$ value } \\
\hline & control $^{\mathrm{i}}$ & T0 ${ }^{\mathrm{ii}}$ & T50 ${ }^{\text {iii }}$ & $\mathrm{T}^{2} 5^{\mathrm{iv}}$ & SE & \\
\hline Co ug/g (DW) & 0.54 & 0.78 & 0.67 & 0.667 & 0.03 & $>0.05$ \\
\hline Co ug/g (WW) & $0.139 \mathrm{a}$ & $0.213 b$ & $0.16 \mathrm{ab}$ & $0.156 \mathrm{a}$ & 0.01 & 0.02 \\
\hline Cu ug/g) (DW) & 52.9 & 43.7 & 54.7 & 31.28 & 4.16 & $>0.05$ \\
\hline $\mathrm{Cu} u g / g(W W$ & 13.22 & 11.4 & 13.98 & 9.76 & 1.02 & $>0.05$ \\
\hline Mn ug/g (WW) & 41.9 & 25.9 & 25.76 & 47.03 & 5.86 & $>0.05$ \\
\hline Mn ug/g (DW) & 10.6 & 6.79 & 7.70 & 12.07 & 1.36 & $>0.05$ \\
\hline Mg ug/g (DW) & $3035.8 \mathrm{a}$ & $2360.6 a$ & $3037.8 \mathrm{a}$ & $1983.6 b$ & 164.0 & 0.04 \\
\hline Mg ug/g (WW) & $761.50 \mathrm{a}$ & $615.70 \mathrm{a}$ & $601.80 \mathrm{a}$ & $430.20 \mathrm{~b}$ & 36.40 & 0.003 \\
\hline Zn ug/g (DW) & 36.4 & 25.6 & 34.6 & 21.62 & 2.4 & $>0.05$ \\
\hline Zn ug/g (WW) & 9.20 & 6.66 & 8.68 & 5.55 & 0.57 & $>0.05$ \\
\hline \multicolumn{7}{|c|}{ a,b,c means in rows with no common superscript differ significantly. } \\
\hline \multicolumn{7}{|c|}{$\begin{array}{l}{ }^{1} \text { Fed corn oil as a source of energy } \\
\text { ii Fed fat instead of corn oil as a source of energy }\end{array}$} \\
\hline \multicolumn{7}{|c|}{$\begin{array}{l}\text { Fed fat instead of corn o1l as a source of energy } \\
\text { iii Fed fat with triticale replacing } 50 \% \text { of corn. }\end{array}$} \\
\hline \multicolumn{7}{|c|}{ iv Fed fat with triticale replacing $25 \%$ of corn. } \\
\hline \multicolumn{7}{|l|}{$W W=$ wet weight } \\
\hline \multicolumn{7}{|l|}{ DW= Dry weight } \\
\hline $\mathrm{E}=$ Standard err & means & & & & & \\
\hline
\end{tabular}


Liver samples have proved useful in anticipating mineral deficiencies in livestock, because the liver is considered as storage organ of certain minerals (Underwood and Suttle, 1999). In this study, hepatic $\mathrm{Zn}, \mathrm{Cu}$ and $\mathrm{Mn}$ concentration were fairly stable, and there was no significant effect of feeding dry fat and triticale on them. This means there is no antagonism between dry fat calcium and utilization of $\mathrm{Zn}, \mathrm{Cu}$ and $\mathrm{Mn}$. Different treatments caused a significant change in Co (WW) and $\mathrm{Mg}$ concentrations in liver. A higher concentration was found in livers of chicks fed the dry fat and triticale. On the other hand, different treatments caused a significantly reduction on the concentration of hepatic $\mathrm{Mg}$ (DW and WW). Generally, most of studies in the area of minerals indicate that the assessment of trace mineral status is difficult, and this remains an important challenge to researchers.

In conclusion, the experiment results demonstrated that triticale can be substituted for corn in broiler diets up to $50 \%$ of the corn grain $(27 \%$ starter and $30 \%$ for finisher diets) without any adverse effect on chicks performance, but a feed conversion ratio higher by almost $20 \%$ was detected. Dry fat and triticale cause a significant increase on lipid percentage in breast and drumstick meat cuts, even though increases in breast meat percentage were found. Moreover, using dry fat and triticale caused a significant change in hepatic $\mathrm{Mg}$ and Co levels. Further research is needed to study the effect of using enzymes to overcome the negative effect of the antinutritional factors in triticale which may reduce nutrients utilization by broiler chicks.

\section{References}

Al-Athari, A. K. and Z. Al- Bustany. 1996. Substitution of maize with different levels of triticale in broiler diets and the effect of enzyme supplementation.
Al- Athari, A. K. and Z. Al- Bustany. 1997. Substitution of maize by triticale and/or barley in broiler diet. IPA J. of Agric. Res. 7:8-16.

AOAC. 1990. Official Methods of Analysis $\left(15^{\text {th }}\right.$ ed.) Association of Official Analytical Chemists, Arlington, VA, USA.

Austin, S., C. Wiseman and J. Chesson. 1999. Influence of non-starch polysaccharides structure on the metabolisable energy of U.K. wheat fed poultry. J. Cereal Sci. 29:77-88.

Beynen, A. C. and K. B. Ketan. 1985. Why do polyunsaturated fatty acids lower serum cholesterol? Am. J. Clin. Nutr. 42:560-563.

Belaid, A. 1994. Nutritive and economic value of triticale as a feed grain for poultry. Mexico, DF. CYMMIT Working paper 94-1, pp.42.

Braggy, D. B., and T. F. Sharby. 1970. Nutritive value of triticale for broiler chicks diets. Poultry Sci. 49:10221026.

Charalambous, K., A. Koumas, and S. Economides. 1986. The effect of triticale grain on the performance of chicks from birth to nine weeks of age. Tech. Bull. Agric. Res. Inst. 79:1-7.

Choct, M., and G. Annison. 1990. Antinutritive activity of wheat pentosans in broiler diets. Br. Poult. Sci. 31:811-821.

Gatel, F., O. Lavorel, J. Fekete, F. Grosjean and J. Castaing. 1985. Feeding value of triticale for monogastrics: weaned piglets, growing-finishing pigs and broilers. In: Bernard, M., S. Bernard (Eds.). Genetics and Breeding of Triticale. 
Institut National de la Recherche Agronomique, Versailles, France. pp.659-670.

Gerry, R. W. 1975. Triticale in broiler rations. Feedstuffs. 47:24-25.

Hermes. J. C. and R. C. Johnson. 2004. Effect of feeding various levels of triticale Var. Bogo in the diet of broiler and layer chickens. J. Appl. Poult. Res. 13:667-672.

Johnson, R. and P. Eason. 1988. Evaluation of triticale for use in diets for meat-type chickens. J. Sci. Food Agric. 42:95-108.

Jones, P.J.H. and D.A Scheeler. 1988. Polyunsaturated: saturated ratio of diet fat influences energy substrate utilization in the human. Metabolism 37:145-151.

King, J. C., D. M. Shames and L. R. Woodhouse. 2000. Zinc homeostasis in humans. J. Nutr. 130:1360S-1366S.

Korver, D. R., M. J Zuidhof and K. R. Lawes. $2004 . \quad$ Performance characteristics and economic comparison of broiler chicken fed wheat and triticale- based diets. Poultry Sci. 83:716-725.

Leeson, S. and J. D. Summers. 1987. Response of White Leghorns to diets containing ground or whole triticale. Can. J. Anim. Sci. 67:583-585.

Mathlouthi, N., L. Saulnier, B. Quemener and M. Larbier. 2002. Xylanase, $\beta$ glucanase, and other side enzymatic activities have greater effects on the viscosity of several feedstuffs than xylanase and $\beta$-glucanase used alone or in combination. J. Agric. Food Chem. 50:5121-5127.
Mercer, S.W. and P. Trayhurn. 1987. Effect of high fat diets on energy balance and thermogenesis in brown adipose tissue of lean and genetically obese ob/ob mice. J. Nutr. 117:21472153.

Mohanna, C. and Y. Nys. 1999. Effect of dietary zinc content and sources on the growth, body zinc deposition and retention, zinc excretion and immune response in chickens. Br. Poult. Sci. 40:108-114.

Myer, R. O., J. H. Brendemuhl and R. D. Barnett. 1996. Crystalline lysine and threonine supplementation of soft red winter wheat or triticale, low-protein diets for growing-finishing swine. J. Anim. Sci. 74:577-583.

National Research Council. 1994. Nutrient Requirements of Poultry. 9th rev. ed. National Academy Press, Washington DC.

Pettersson, D. and P. Aman. 1988. Effects of enzyme supplementation of diets based on wheat, rye or triticale on their productive value for broiler chickens. Anim. Feed Sci. Technol. 20:313-324.

Proudfoot, F. G. and H. W. Hulan. 1988. Nutritive value of triticale as a feed ingredient for broiler chickens. Poult. Sci. 67:1743-1749.

Ruiz, N., E. Marion, R. D. Miles and R. B. Barnett. 1987. Nutritive value of new cultivars of triticale and wheat for broiler chick diets. Poult. Sci. 66:9097.

Rundgren, M. 1988. Evaluation of triticale given to pigs, poultry and rats. Anim. Feed Sci. Technol. 19:359-375.

Saleh, E. A., S. E. Watkins, A. L. Waldroup and P. W. Waldroup. 2004. Effects of dietary nutrient density on 
performance and carcass quality of male broilers grown for further processing. Internat. J. of Poult. Science. 3(1):1-10.

Sell, J. L., G. C. Hodgson and L. H. Shebeski. 1962. Triticale as a potential component of chick rations. Can. J. Anim. Sci. 42:158-166.

Shimomura, Y., T. Tamura and M. Suzki. 1990. Less body fat accumulation in rats fed a safflower oil diet than in rat fed a beef tallow diet. J. Nutr. 120:1291-1296.

Smith, R. L., L. S. Jensen, C. S. Hoveland and W. W. Hanna. 1989. Use of pearl millet, sorghum, and triticale grain in broiler diets. J. Prod. Agric. 2:78-82.

Smits, C. H. M. and G. Annison. 1996. Non-starch plant polysaccharides in broiler nutrition-towards a physiologically valid approach to their determination. World's Poult. Sci. 52:203-221.

Steel R. G. and Torrie J. H. 1980. Principles and Procedures of Statistics. $2^{\text {nd }}$ ed. McGraw-Hill New York.
Takeuchi, H., M. Tatsuhoro, K. Tokutama, Y. Shimomura and M. Suzuki. 1995. Diet-induced thermogenesis is lower in rats fed a lard diet than in those fed a high oleic acid safflower oil diet, a safflower oil diet or a linseed oil diet. J. Nutr. 125:920-925.

Underwood E. J. and N. F. Suttle 1999. The mineral Nutrition of Livestock. $3^{\text {rd }}$ ed. CABI publishing. Oxon. UK.

Vieira, S. L., A. M. Penz, A. M. Kessler, and E. V. Catellan, Jr. 1995. A nutritional evaluation of triticale in broiler diets. J. Appl. Poult. Res. 4:352-355.

Vohra, P., S. Bersch, C. Q. Qualset and R. Baker. 1991. Triticale: An alternative cereal grain in broiler starter diets. Calif. Agric. 45:34-37.

Wilson, K. J. and Bayer, R. S. 2000. Poultry Nutrition Information for Small Flocks.

http://www.oznet.ksu.edu/library/lvstk 2/ep80.pdf 